\title{
Literature Review on Failure Analysis Transmission Tower Design
}

\author{
Swarup Sontakke $^{1}$, Dr. Sakhale ${ }^{2}$, Ashutosh Trivedi ${ }^{3}$ \\ ${ }^{1,2}$ Mechanical Engineering Department, Priyadarshini College of Engineering, Nagpur - India. \\ ${ }^{3}$ Sterlite Power Transmission Limited, New Delhi-110065, India
}

\begin{abstract}
Dated on 27-04-2018 tower had failed at Trans rail Testing Center in Wardha, India. This article examined how failure of "MD" (300 -600 Dev./D.E.-00) NT +9M Body Extension 220 Kv Multi - Circuit Transmission Tower design. The poor design Transmission Tower Structure directly related with load behaviors on each component elements of transmission tower Structure. Failure were observed that during testing load applied on transmission tower structure at That were observed MD type tower withstood load up to $50 \%$, while reaching near $75 \%$ load, belt member item no. 562 of $+9 M$ B.E \& Center plate item no. 563 buckled, subsequently other item no. 560,543,544,535,536 \& 537 got damaged/failed.

Data were collected from failure analysis of physical testing and previous reason of failure transmission tower with the help of study journal research paper based on the failure transmission tower design. Also study of Government \& Non-Government organization tower failure data.After analysis of all failure reason, Project is advice to use Finite Element method, Practical Proto type tower testing Using this way tower design can be easily modified and updated. By using this way Testing \& FEM, the result will saving of time cost and tool. Theoretical \& Practical implications of results are discussed.
\end{abstract}

.Keywords- MD type $220 \mathrm{kV}$ Multi-Circuit Transmission Tower, Proto Type Testing practical, Failure member, over all failure reason of structure, Forces

\section{I- INTRODUCTION}

A transmission tower (sometimes called a power transmission tower, power tower, or electricity pylon) is a tall structure (typically made of steel lattice) that supports an overhead power line. They are used in electrical grids to deliver bulk electric power from producing units to electrical substations through highvoltage transmission lines Lower-voltage subtransmission and distribution lines transmit electricity from substations to electric consumers, and utility poles are used to sustain them.

Transmission tower structural design is critical in the power distribution network and is frequently subjected to tremendous loads. The linear response to varying loads is frequently used in the design of lattice towers. The transmission tower's structural design must carry the heavy transmission cables at a suitable safe height above the ground. Furthermore, all towers must withstand a variety of natural disasters. As a result, transmission tower design is a critical engineering task that utilises civil, mechanical, and electrical engineering ideas. Dated on 27-04-2018 tower had failed at Transrail Testing Centre in Wardha, India, This article examined how failure of "MD" $\left(30^{0}-60^{0}\right.$ Dev./D.E. $\left.-0^{0}\right) \mathrm{NT}+9 \mathrm{M}$ Body Extension $220 \mathrm{kV}$ Multi - Circuit Transmission Tower design. The poor design Transmission Tower Structure 


\section{International Journal of Innovations in Engineering and Science, www.ijies.net}

directly related with load behaviours on each component elements of transmission tower Structure. Failure were observed that during testing load applied on transmission tower structure at That were observed MD type tower withstood load up to $50 \%$, while reaching near $75 \%$ load, belt member item no. 562 of +9 M B.E \& Centre plate item no. 563 buckled, subsequently other item no. $560,543,544,535,536 \& 537$ got damaged/ failed

During the earlier testing the structure design of transmission tower is failed as per above paragraph, to improve the efficiency and effectiveness transmission structure tower Theoretical \& Practical implication of results are discussed

With the aid of a study journal research article based on the failure transmission tower design, data was collected from failure analysis of physical testing and prior reasons for failure transmission tower. In addition, data on tower failures from government and non-government organisations is being studied.

Transmission line tower failure analysis is the most critical part of transmission line tower design. Even if they are carefully designed according to several codal regulations, the tower may fail in certain circumstances. Hence a designed transmission tower must be tested either experimentally or analytically before implementing the actual design in the field.. These test findings reveal the towers' failure mechanism, which may be eliminated by employing different strengthening strategies.

\section{II- LITERATURE REVIEW}

1) "Failure analysis of transmission line towers" $P$. Sethupathi 1, Dr.P.K.Umesha2, P. Sarala 3,1,3Prathyusha Engineering College, Chennai, India Chief Scientist \& Head, Tower Testing \& Research Centre, CSIR - SERC, Chennai, India

During full scale testing of transmission line towers at the Tower Testing and Research Station, Structural Engineering Research Centre, Chennai Indian, numerous sorts of early failures were detected. The model was developed and evaluated using finite element software. This research demonstrates that a nonlinear static analysis is required to comprehend the structure's behaviour, likely load bearing capability, design flaws, and instability.

2) "Studies on failure of transmission line towers in testing”; N. Prasad Rao; G.M. Semuel Knight; S.J. Mohan; N. Lakshamanan, ELSEVIER-2011.:-

Different forms of early failures discovered during full scale testing of transmission line towers at Tower
Testing and Research Station, Structural Engineering Research Centre, Chennai are described in this research on towers. Failures identified during testing are investigated and the causes are described in depth. Different types of failures are modeled using finite element software and the analytical and the test results are compared with various codal provisions. The general Fem analysis programme NE- The effect of nontriangulated hip bracing pattern and isolated hip bracings connected to elevation redundant in ' $\mathrm{K}$ ' and ' $\mathrm{X}$ ' braced panels on tower behaviour are studied. The tower members are modelled as beam column and plate elements

3) Failure analysis of transmission towers"; F. Albermani; S. Kitipornchai; R.W.K. Chan, ELSEVIER-2008:-

The main aim of this paper is to present results of a fullscale pushover test of a 40 meter telecommunication tower under breaking load. A detailed description of the studied tower has been presented with emphasis on the geometrical imperfections of the selected members of the structure.

The experiment's findings were provided, which included the axial forces in the tower's members as well as the displacements of the observed nodes as a function of external load. For a typical set of communications equipment, a comparison of a wind load based on existing norms with a load based on experimental breaking force has been examined. The key result was that the total carrying capacity of the structure was determined by the legs' buckling resistance. Furthermore, the predicted buckling resistances of the tower's legs consisting of round solid bars (based on standards) were lower than the experimental axial forces under compression.

4) "Analysis And Design Of Transmission Tower ",Gopi Sudam Punse, Vol. 4 | Iss. 1 | Jan. 2014 |118, IJMER | ISSN: 2249-6645:-

In this thesis, the analysis and design of a narrow-based Transmission Tower (using Multi Voltage Multi Circuit) is carried out in India with the goal of providing the best possible use of electric power with the available ROW and the growing population in the area. Transmission Line Towers account for around 28 to 42 percent of the overall cost of transmission lines. The growing demand for electrical energy may be handled more costeffectively by designing various light-weight transmission line tower types. By contemplating a unique transmission line tower construction, an attempt has been made in this project to make the transmission 


\section{International Journal of Innovations in Engineering and Science, www.ijies.net}

line more cost efficient with the goal of providing optimal electric supply for the needed region. The goal of this study is to improve the existing system by using a $220 \mathrm{KV}$ and $110 \mathrm{KV}$ Multi Voltage Multi Circuit with narrow based Self Supporting Lattice Towers. The tower was analysed and designed as a three-dimensional structure using STAAD PRO v8i. The tower members are then designed.

5) Umesh S. Salunkhe and Yuwaraj M. Ghugal (2013)," Analysis And Design Of Three Legged 400kV Double Circuit Steel Transmission Line Towers International Journal" Vol. 04, Issue 3.

The main objective of this paper is to determine the most economical section of tower and its configuration as per Indian Standard IS-800. The present work describes the analysis and design of four legged self-supporting 220 $\mathrm{kV}$ double circuit steel transmission line towers models with an angle, tubular and channel sections. In this study dead load and wind load as per IS: 802 (1995) are taken into account in these three models. STAAD. Pro program has been used to analysis and design the members of $220 \mathrm{kV}$ double circuit tower. A comparative study is conducted with respective to axial forces, deflections, maximum sectional properties, critical loading conditions between these three models of tower. The study shows that tower with angle sections are most economical and effective section compared to other two sections. The transmission tower has a height of $40 \mathrm{~m}$ and square base width of $11.5 \mathrm{~m}$. The members are also grouped for better fabrication. Steel optimization has been carried out to find the most suitable and economical section for the design.

6) Srikanth L.and Neelima Satyam D (2014), "Dynamic Analysis Of Transmission Line Towers International Journal, Environmental, Structural, Construction and Architectural Engineering Vol: 8, No:4.

The towers of the to the most powerful life-line buildings that support electrical transmission line are peculiar transmission. Transmission towers are essential for providing energy to various parts of the nation. The transmission line should be stable and carefully structured with the objective that they do not fizzle in the midst of a cataclysmic event and adapt to the national and universal standard. This present paper manages the investigation of static and dynamic examination of transmission line tower. A run of the mill sort of transmission line tower is picked as contextual analysis. The examination and displaying of pinnacle is done utilizing FE based ANSYS programming. The heaps following up on the pinnacle reflected are numb burden, live burden and dynamic burdens .in this Paper the most extreme twisting joined anxieties and characteristic frequencies ,bowing minute shear constrain are gotten.

7) Dharmender Panth, IIT-BHU, Varanasi, U.P., India, Reasons For Failure Of Transmission Lines And Their Prevention Strategies, Volume-2, Issue-1, Jan.-2014:-

Transmission line towers, though designed per code provisions, may fail during mandatory testing required in many countries, which leads massive damage to power system. Different types of premature failures that are observed during various full-scale testing of transmission line towers and their results are discussed in detail. Importance of design assumptions and connection detailing in overall performance of towers were studied. Importance of secondary member design and connection detail in overall performance of the tower was studied. Non-linear finite element analysis is useful in understanding the system behavior and for prediction of failure pattern and ultimate load. Based on the test results the importance of studying the failures is highlighted. The need for implementing various failure prevention strategies in transmission line towers has also been emphasized lucidly.

8) Rao NP, Knight GS, Mohan SJ, and Lakshmanan N (2012). Studies on failure of transmission line towers in testing. Engineering Structures, 35: 55-70. :-

Different types of premature failures observed during full scale testing of transmission line towers at Tower Testing and Research Station, Structural Engineering Research Centre, Chennai are presented. Failures that have been observed during testing are studied and the reasons discussed in detail. The effect of nontriangulated hip bracing pattern and isolated hip bracings connected to elevation redundant in ' $\mathrm{K}$ ' and ' $\mathrm{X}$ ' braced panels on tower behaviour are studied. The tower members are modelled as beam column and plate elements. Different types of failures are modelled using finite element software and the analytical and the test results are compared with various codal provisions. The general purpose finite element analysis program NENASTRAN is used to model the elasto-plastic behaviour of towers. Importance of redundant member design and connection details in over all performance of the tower is discussed

9) A. Hamada, A.A. El Damatty, "Failure Analysis of Guyed Transmission Lines During F2 Tornado Event", 0141-0296/_2014 Elsevier Ltd

Most wind-related transmission line failures have been attributed to high intensity wind (HIW) events in the form of tornados and downbursts. In the current study, a 


\section{International Journal of Innovations in Engineering and Science, www.ijies.net}

numerical model is developed to investigate the performance of two guyed transmission lines under tornado wind loads. The F2 tornado wind field used in the study is based on a computational fluid dynamics (CFD) analysis that was developed and validated in previous studies. The tornado wind forces are calculated and are then incorporated into a three-dimensional nonlinear finite-element model that simulates both the towers and the conductors. The study investigates the effect of tornado loads on the structural performance of the two different guyed transmission line systems. The tornado locations leading to maximum internal forces in various members of the towers are identified and are considered as critical load cases. The nonlinear numerical model is then extended to study the progressive failure of the two transmission lines under the critical tornado load cases by varying the velocity of the tornado wind fields incrementally. The velocities at which a total collapse is predicted are identified for both towers

10) Zinnia Nair; K. M. Aparna; R. S. Khandagale; And T. V. Gopalan, "Failure Of $220 \mathrm{Kv}$ Double Circuit Transmission Line Tower Due To Lightning", 10.1061/ Asce! 0887-3828 2005!19:2 132!

A case of failure of bracings and the associated leg member of a $220 \mathrm{kV} 220 \mathrm{kV}$ double circuit, transmission line tower was reported from one of the State Electricity Boards of India. The bracings sustained extensive damage and there was visible bending in the leg member. All these members sustained blotches. Except for severe lightning, the weather was normal. Investigations into the causes of failure of the tower brought out that the tower members failed due to temperature induced forces, the temperature rise being due to lightning currents flowing through the members. An analysis of temperature stresses in failed members, their buckling strength, etc. done as a part of the investigation is detailed in this paper.

\section{III - CONCLUSION}

Various types' untimely failures \& the reasons were discussed. The study shows that the various types of failure is useful to understanding the behavior, load carrying capacity. During the literature review, \& after analysis of all failure reason, Project is advice to use Finite Element method, Practical Proto type tower testing Using this way tower design can be easily modified and updated. By using this way of Testing \& FEM, the results will saving of time cost and tool.
Theoretical \& Practical implication of results are discussed

Also the few identify problem are as follows

$>$ Various types of Load as mentioned in literature review

$>$ Coupling of structure truss member are poor designed

$>$ Low grade raw material used for structure developing

$>$ Lower section steel angle are used

$>$ Traditional method Tower design without considering various type of load

$>$ The grade of raw material has poor capacity of hidden load sustaining

\section{REFERENCES}

[1] Failure Test report "MD" $\left(30^{\circ}-60^{\circ}\right.$ Dev./D.E. $\left.-0^{\circ}\right)$ NT $+9 M$ body extension $220 \mathrm{kV}$ multi - circuit transmission tower design.

[2] IS 802 Part 1 Sec 11995 Code of practice for use of structural steel in overhead transmission line towers, Part 1

[3] Ch. Sudheer (2013), "Analysis And Design Of $220 k v$ Transmission Line Tower In Different Zones I \& V With Different Base Widths - A Comparative Study "International Journal Of Technology Enhancements And Emerging Engineering Research, Vol 1, Issue 435 Issn 2347-4289

[4] C. Preeti 1) and K. Jagan Mohan (2013) , " Analysis of Transmission Towers with Different Configurations" Jordan Journal of Civil Engineering, Volume 7, No. 4.

[5] Yoganantham.C Helen Santhi.M (2013), "Dynamic Analysis of Transmission Towers International Journal of Advanced Information Science and Technology (IJAIST)", Vol.20, No.20.

[6] Umesh S. Salunkhe and Yuwaraj M. Ghugal (2013)," Analysis And Design Of Three Legged $400 \mathrm{kV}$ Double Circuit Steel Transmission Line Towers International Journal of Civil Engineering and Technology" Vol. 04, Issue 3.

[7] Srikanth L.and Neelima Satyam D (2014), "Dynamic Analysis Of Transmission Line Towers International Journal of Civil, Environmental, Structural, Construction and Architectural Engineering Vol:8, No:4.

[8] Dharmender Panth, IIT-BHU,Varanasi, U.P., India, Reasons For Failure Of Transmission Lines And Their Prevention Strategies, Volume-2, Issue-1, Jan.-2014

[9] Siti Aisyah Kamarudin , Fathoni Usman, Intan Nor Zuliana Baharuddin "Review on analysis and design of lattice steel structure of overhead transmission tower" College of Graduate Studies, Universiti Tenaga Nasional, Kajang, Malaysia ,Institute of Energy Infrastructure, Universiti Tenaga Nasional, Kajang, Malaysia 
Vol. 6, No. 8, 2021, PP. 44-48

International Journal of Innovations in Engineering and Science, www.ijies.net

[10] Vinay RB, Ranjith A, and Bharath A (2014). Optimization of transmission line towers : P-Delta analysis. International Journal of Innovative Research in Science, Engineering and Technology, 3(7): 1456314569.

[11] Usman F and Megat Asyraf MIR (2011). Simulation of progressive collapse for transmission tower. In the 1st TNB ICT Technical Conference, College of Information Technology, Universiti Tenaga Nasional, Kajang, Malaysia.

[12] Rao NP, Knight GS, Mohan SJ, and Lakshmanan N (2012). Studies on failure of transmission line towers in testing. Engineering Structures, 35: 55-70.

[13] Rao NP and Kalyanaraman V (2001). Non-linear behaviour of lattice panel of angle towers. Journal of Constructional Steel Research, 57(12): 1337-1357. 